\section{Erland Kolding Nielsen}

\subsubsection{7-22.1.2017}

Fhv. direktor for Det Kongelige Bibliotek Erland Kolding Nielsen afgik ved doden 22. januar 2017 efter kort tids sygdom.

Umiddelbart inden havde bibliotekets medarbejdere sagt farvel til Kolding Nielsen ved hans afskedsreception den 11. januar. Den planlagte afskedsreception for eksterne samarbejdspartnere 26. januar blev afholdt alligevel, men fik form som en mindekoncert. Biblioteket takker alle for deltagelsen.

"Tidligere direktør for Det Kgl. Bibliotek, Erland Kolding Nielsen, er afgået ved døden efter kort tids sygdom. Erland Kolding Nielsen var en markant personlighed i det danske kulturliv og i den internationale biblioteksverden. Hans indsats som chef for Det Kgl. Bibliotek i perioden 1986-2016 var omfattende og trak lange spor. Indsatsen har sit mest storslåede udtryk i Den Sorte Diamant, den imponerende bygning, som næppe var blevet til noget uden Erland Kolding Nielsens vedholdende indsats.

Erland Kolding Nielsen havde som bibliotekschef et meget bredt interessefelt. Men historien og musikken var noget særligt for ham, og han gjorde en stor indsats for at formidle kendskabet til dansk musik. Også uden for Det Kgl. Bibliotek ydede Erland Kolding Nielsen en stor indsats for biblioteksvæsenet. Han var en veltalende ambassadør for biblioteker på tværs af sektorer, og han argumenterede velforberedt og veloplagt for gode vilkår for bibliotekerne.

Erland Kolding Nielsens viden var omfattende, og han delte den gerne. Hans

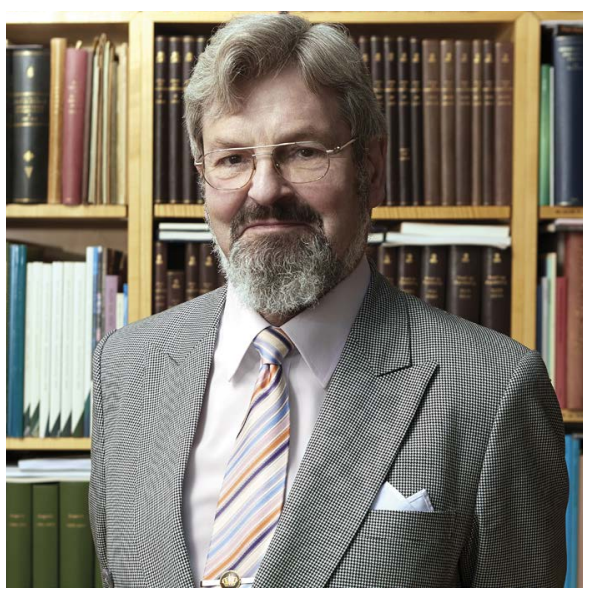

arbejdsindsats var legendarisk, og tog ind imellem pusten fra omgivelserne. Ved siden af posten som chef for Det Kgl. Bibliotek var Erland Kolding Nielsen medlem af en lang række bestyrelser, råd og udvalg, hvor han også lagde en stor arbejdsindsats. Det internationale arbejde havde hans store bevågenhed, og hans indsats her er meget værdsat. Som kollega var han hjælpsom, men samtidig en udfordring i kraft af sine stærke og klare standpunkter. Han elskede at krydse klinger i en diskussion og kunne den ædle kunst at anerkende et godt argument fra modparten. Som person kunne han umiddelbart opleves som dominerende, men han var sine venners ven, og i kollegers kreds var det den ligefremme og muntre tone, der fyldte.

Det Kgl. Bibliotek vil i mange år nyde godt af Erland Kolding Nielsens omfattende indsats som chef, og han vil blive husket og respekteret for sit store engagement og sin helt enorme arbejdsindsats for bibliotekerne. Erland Kolding Nielsen blev 70 år."

Svend Larsen, direktor 